\title{
In and Out of Sight: The Afterlife of Official Photography from Idi Amin's Uganda*
}

\author{
RICHARD VOKES \\ University of Western Australia \\ https://orcid.org/0000-0003-2862-7203
}

\begin{abstract}
This article examines the output of Uganda's official Photographic Section from the years of the Idi Amin regime (1971-9), an archive of 60,000 black and white images from which have recently come to light in the stores of the Uganda Broadcasting Corporation in Kampala. Drawing on recent developments in African visual studies, the article focuses in particular upon what this archive reveals about photographic circulations in and from Amin's Uganda. It finds that this new trove of negatives when compared with press archives from around the world - is especially revealing of a growing nexus between official photography and all kinds of commercial photographies in the 1970s. This nexus played a key role in shaping both how the Amin regime was pictured at the time, and how its afterlife has continued to reflect down to the present time.
\end{abstract}

In recent years, the fields of visual studies in general, and of the history of photography in particular, have become increasingly defined by what Deborah Poole has previously described as a 'move ... away from a concern with representation per se in favour of the more complex discursive and political landscapes opened up by the concepts of media and the archive.' ${ }^{1}$ In other words, whereas once these fields were dominated by analyses of narrowly semiotic questions of representation and power, today their focus has become much more upon the social and historical contexts within which image-objects are created, through which they are circulated, and within which they are consumed. Within the study of African photographies, specifically, this wider shift has generated new empirically rich case studies of, for example, the social and political milieu that shaped production in and through Africa's photographic studios from the late nineteenth century onwards; the circuits of exchange through which photographic image-objects produced in Africa were projected across

This article is the outcome of a larger project that is a collaboration between the UBC, The Uganda Museum, the University of Michigan, and UWA. I would especially like to thank the UBC's Managing Director Winston Agaba and Deputy MD Maurice Mugisha, the Museum's Commissioner Rose Mwanja Nkaale and its Head of Ethnography Nelson Abiti, UofM's Professor of History and African Studies Derek R. Peterson, and Makerere University's Lecturer in History Edgar C. Taylor, for all of their incredible work on the project.

I would like to thank Kronos co-editor Patricia Hayes, and two anonymous reviewers for the journal, for their erudite comments and suggestions. I would especially like to thank Derek R. Peterson for his thoughtful discussions on an earlier draft. Of course, any mistakes or omissions remain mine alone.

1 D. Poole, 'An Excess of Description: Ethnography, Race, and Visual Technologies', Annual Review of Anthropology, 34, $2005,159$. 
localities, regions and the globe, since the advent of photography; and the myriad ways in which Africans have used photographic images as a tool for forging both individual and collective identities, down to the present time. ${ }^{2}$

However, in perhaps no area have the new strategies been as transformative as they have been in relation to our understanding of the history of official, or administrative, photographies in Africa. Simply put, this is because for a long time these kinds of official photography were largely read by scholars in narrowly semiotic terms. In other words, they were primarily analysed as a generic form of colonial imagery which, in representing 'official state events, civic life, examples of "progress" and portraits for helping categorize individuals," served 'both to symbolise the power differential in the colonies, and to bring it into visible order. ${ }^{4}$ Yet following the advent of the 'new' analytical strategies (as it were), a raft of more contextually focused case studies have instead drawn attention to how in many African settings, governmentsponsored photography often emerged from milieux that were outside of official governance, and which also generated other, more independent, kinds of imagery at the same time. For example, Buckley's studies of 'official' photography in colonial Gambia have shown that much of this imagery was actually produced by commercial photographers, who the government employed as a means for gaining a 'vernacular window' on the administration's policies. ${ }^{5}$ So too, these studies have highlighted how such imagery was sometimes circulated, and recirculated, in ways that were outside of colonial governments' control, and in ways that resulted in it being cast 'against the grain. Finally, these newer accounts have also highlighted how official photography may invoke peculiar complexities of reception, and how these may become in some cases more vexed with the passing of time. In all of these ways, then, an earlier view of official photography as primarily a genre of coercion, has become replaced with a more nuanced understanding of a complex field of overlapping - and at times counterintuitive, perhaps even contradictory - practices and effects.

All of this helps to frame the present article, which is a study of Uganda's official Photographic Section during the period of the Idi Amin regime (1971-9) - 60,000 black and white negatives which have recently come to light in the stores of the Uganda Broadcasting Corporation (UBC) in Kampala ${ }^{6}$. The aim of the article is less to develop a survey of the archive's overall content, or to expand upon its semiotics per se, so much as to trace the multiple relations - political, institutional and interpersonal - from which it was produced, through which it was circulated, and by way of which its images became ultimately 'endowed with meaning and purpose.?

2 I have previously published two overviews of recent scholarship on African photographies: R. Vokes, 'Introduction', in R. Vokes (ed), Photography in Africa: Ethnographic Perspectives (Oxford: James Currey, 2012), and R. Vokes, 'Photographies in Africa in the Digital Age', Africa, 89, 2, 2019, 207-24. See these other publications for relevant examples and references here.

L. Buckley, 'Cine-Film, Film-Strips and the Devolution of Colonial Photography in the Gambia', History of Photography, 34, $2,147$. Edwards, cited in J. Peffer, Art and the End of Apartheid (Minneapolis: University of Minnesota Press, 2009), 242.

Buckley, 'Cine-Film.

These negatives have been the main focus of our larger digitization and research project. For more on how the project came about, see R. Vokes, 'Signs of Development: Photographic Futurism and the Politics of Affect in Uganda', Africa, 89, 2, 2019, 311-312, and Peterson and D.R. Peterson and R. Vokes, The Unseen Archive of Idi Amin: Photographs from the Uganda Broadcasting Corporation (Munich: Prestel, 2021). The UBC's total photo archive is around 85,000 negatives, including the 60,000 from the Amin years. To date, our project has digitised around 50,000 of the total.

7 E. Edwards, 'Photographs and the Sound of History', Visual Anthropology Review, 21, 1-2, 2005, 29. 
Within this, my particular interest is in how these multiple relations forged a growing nexus between circuits of official and commercial photography in Amin's Uganda, and how this in turn produced a series of peculiar effects upon which images were circulated, and how. Specifically, and as I will go on to further argue, it is only by considering these wider contexts that one is able to understand why and how some images taken by the Photographic Section have come to occupy a central place within the global visual archive of the Idi Amin years, whilst many others (the vast majority, in fact) have literally never been seen before. Moreover, it is only by these means that we can further appreciate the peculiar afterlife of the photographic archive from Amin's Uganda, in which the 'global visual imaginary' of this period has long since come to be dominated by images of a small number of subjects, all of which were, in various ways, in fact unrepresentative of the Ugandan experience of this time. In other words, I am interested in how these circulations have served to reinforce a particular kind of 'myth-making' about this period in the country's history. ${ }^{8}$

\section{The Photographic Section, 1947-71}

The official media apparatus that Idi Amin inherited was set up by the British colonial administration in 1947, and passed down through Milton Obote's post-independence government. From the time of its creation, what became the Ministry of Information had reflected two deep-seated impulses within national governance. The first was an 'inward-focused' desire to expand the use of all kinds of media - from photography, to newspapers, film and radio - as tools for accelerating social and political development inside the country. The second was a more 'outward-facing' interest in using new media also as a tool for expanding Uganda's visibility 'back home' in the UK, and throughout the rest of the world. This latter impulse traces, ultimately, to a series of pre-Second World War efforts aimed at stimulating greater interest in Britain's colonies among wider publics in the UK, and elsewhere, in order to grow imperial trade. Thus, following the staging of the seminal British Empire Exhibition at Wembley Park in London in 1924-5, the British government had embarked on a series of similar initiatives aimed at promoting the colonies on a global scale, and each of these had become progressively more 'media savvy' in its approach. ${ }^{9}$

I have elsewhere written extensively about the ways in which Uganda's official Photographic Section contributed to national 'social marketing' campaigns, and to political advertising. ${ }^{10}$ So my focus here is upon the contribution that it also made towards the second impulse described above, through its production of an ever wider

See M. Leopold, 'Sex, Violence and History in the Lives of Idi Amin: Postcolonial Masculinity as Masquerade', Journal of Postcolonial Writing, 45, 3, 2013, 321-30, and M. Leopold, 'Print the Legend: Myth and Reality in The Last King of Scotland', in N. Eltringham (ed), Framing Africa: Portrayals of the Continent in Contemporary Mainstream Cinema (New York: Berghahn Books, 2013).

9 The most important of these initiatives was undoubtedly the Empire Marketing Board. Led by the UK’s Secretary of State for the Colonies, Leo Amery, during the seven years of its existence (from 1926-32), the Board spent over $£ 1$ million on promoting the empire through public exhibitions, lectures, and posters, and in newspaper and cinema advertising. The Board also sponsored the establishment of a wide range of empire-branded consumer products. See D. Meredith, 'Imperial Images: The Empire Marketing Board, 1926-32', History Today, 37, 1, 1987.

10 See for example R. Vokes, 'Photography, Exhibitions and Embodied Futures in Colonial Uganda, 1908-1960', Visual Studies, 33, $1,2018,11-27$. 
range of visual publicity that was aimed less at Ugandan civilians, and more at international publics. A key example of this is the annual photographic 'Uganda Calendar', the distribution of which was divided 50:50 between organisations and companies inside Uganda (although with an emphasis on foreign embassies and international firms), and overseas recipients. Already by 1952, copies of the calendars - each of which was richly illustrated with images of Ugandan landscapes and wildlife, ethnographic scenes, iconic public buildings and modernist infrastructure - were being distributed to official organisations and imperial companies across London and throughout the empire (including to Canada, India and the Caribbean), and to other European governments, such as Germany and Ireland. So too, the Section's photographs were used to illustrate an increasing range of tourism promotions, including boards for tourist exhibitions both in Uganda and overseas, the pictorially rich 'Uganda Tourism Handbook', a series of tourist pocketbooks and a series of 25 picture postcards, which within a few months of their launch were being regularly circulated across the globe. In addition, Section photographs were incorporated into a wide range of trade and industry-focused materials, including the promotional publications of the Uganda Development Corporation; a commercial-facing quarterly magazine called the Uganda Review; and the very many 'briefing papers' and 'information folders' that were routinely prepared for visiting trade and other international delegations. The Section's photographs were frequently also printed in newspapers and magazines, both in the Ugandan government's own official news sheets, and in a wide range of international publications - in which the Section regularly placed 'pictorial stories' (on average four or five times per year). However, most significantly of all, in 1952, the Section signed an exclusive agreement with a then recently created London-based picture agency - Camera Press - for the commercial sale of their imagery to media outlets worldwide. ${ }^{11}$ By 1959 , Camera Press was regularly selling their pictures to newspapers and periodicals based in at least 18 countries, including to outlets in Brazil, Finland, Greece, Israel, Japan, Switzerland, Thailand (Siam) and Venezuela. I would also emphasise that all of this visual publicity, in addition to being output across such a wide range of media, was also circulated on a quite extraordinary scale. Helpfully, the Section kept meticulous records of their output, and as a result I am able to note that, for example, the Calendar grew from an initial annual print run of 5000 to 8000 per annum; the Section's 25 picture postcards had been, within a year of their production, used to produce 67,000 copies; and at least two tourist publications - the 'Uganda Handbook' and a pocketbook called '50 Facts about Uganda' - each had print runs of more than 50,000. Equally impressive are the overall numbers. Thus, if between 1947 and 1960, the Section had produced 14,000 negatives, over the same period these were used to make 134,440 prints. This is a ratio of more than 1:9, which is an extremely high number for this period. ${ }^{12}$

Following independence in 1962, the government of Milton Obote, and especially his Minister of Information, Broadcasting and Tourism, Alex Ojera, generally

11 Camera Press today remains one of the largest commercial picture agencies in London.

12 I would like to thank my colleague Greg Acciaioli for his discussions on this point. 
emphasised other kinds of media, rather than photography, as their favoured instruments for internal social marketing. As a result, the decade saw rapid advancements in Uganda's newsprint, film, radio and television infrastructures. Nevertheless, I know of at least one instance in which the work of the Photographic Section, whose daily routines of production continued unabated, was used for educational purposes: in a textbook that was made to support the high school curriculum in 'Civics'. More importantly, for my story here, the Section continued to contribute images to at least some publications which were targeted at international tourist and business markets. Examples include a glossy promotional book called Uganda: Pearl of Africa, which was published just after independence (on 9 October 1962), ${ }^{13}$ and a richly illustrated visitor's guide called simply 'Uganda', which was produced in 1963. It also contributed photographs to news publications, including to the Ugandan government's own newspapers, ${ }^{14}$ and to international titles, via Camera Press (although it is also the case that these dropped off sharply, in line with the rapidly declining international 'newsworthiness' of Uganda after independence).

\section{The Official-Commercial Photography Nexus}

Following Idi Amin's rise to power in January 1971, these two official impulses, of using media for national development and of engaging it as a tool for overseas publicity, continued to hold. So too, the trend towards an official emphasis upon other kinds of media, and especially radio, also continued apace. However, unlike with the previous regime, both Amin himself, and members of his inner circle, were also fascinated by the possibilities of still photography. As a result, the Photographic Section was given a series of boosts. The most significant of these occurred in 1974, when the Ministry enacted a plan to establish a government photographer in every province across the country. ${ }^{15}$ That same year, Amin also set up his own personal media unit, which included stills photographers, to provide yet further coverage of his own public and private engagements. (And it is important to note that throughout the remainder of the 1970s, these personal presidential photographers continued to be housed in the Photographic Section's offices, in Nile Avenue's 'Room 10', and to use its facilities to process and catalogue all of their films.) Nevertheless, these continuities should not obscure a number of significant, and interrelated, shifts that occurred during the Amin period, each of which profoundly altered the Section's quotidian routines, and - of central importance for my argument here - the ways in which its photographs were circulated, or were restricted from circulating.

The first of these significant developments was the emergence of additional circuits of official photography. In particular, sometime around 1973, the army set up its own photography team, headed by an officer called Wamala. Similarly, the State

14 Indeed, the 1964 annual report describes this as the Section's main purpose of operations. See Republic of Uganda, Uganda Report (Entebbe: Government Printer, 1964).

15 Although the plan was never fully realised, the government spent a great deal of money on it. Kabarole District Archives box 271, folder 1: P.S. Ministry of Information to all Provincial Governors, 17 November 1977. 
Research Bureau (SRB), Amin's secret police service, established a photographic capability. The appearance of both of these other units affected the day-to-day operations of the Photographic Section in a variety of ways, which appear to have raised tensions around the place. As described to me by one former Section photographer, whenever the army photographers were around (as they often were), one had to exercise a high degree of caution. As he put it: 'It was a military government!...It was a bit rough. So you had to learn how to deal with them [the army photographers]... and to avoid anything that you think would bring problems. We used to avoid clashing with them. ${ }^{16}$ Even more insidious were the effects of the SRB operation, which operated in the shadows. As one former district information officer, Dick Kasolo, who spent a good deal of time at the Section's offices, put it to me, it was precisely because the Ministry photographers did not know who the SRB cameramen were, that they came to imagine the Bureau people to be everywhere - even among their own colleagues. As this respondent went on: 'you had to be very careful [around other photographers] because some of them were spies. There were spies everywhere!' And he emphasised this point over and over again. ${ }^{17}$

However, the major development of the 1970s with which I am mostly concerned in this article is the growing nexus between official and commercial photographies. Interestingly, this shift appears to have been initially driven largely by Idi Amin himself. Thus, from the time he came to power, in addition to expanding the Section's operations, the new president began to also patronise a range of commercial photographers, who were commissioned to take yet more pictures of Amin's public and private affairs. For example, a photographer called Manu Kanani - who was the owner-operator of a studio called Camera Centre on Wilson Road in Kampala - was granted privileged access for this purpose, as was the commercial cameraman Elly Rwakoma. Although Rwakoma's studio was in Jinja, he had secured the position after sending Amin the gift of a lavish album of photographs that he had taken of the new president at various public events. So impressed was Amin with the album, that he invited Rwakoma to come and picture some of his private affairs as well, from which the pair went on to develop a close relationship. ${ }^{18}$ Indeed, it may well have been Amin's early interactions with these commercial photographers that later gave him the idea of setting up a dedicated presidential unit. Yet it was following the expulsion of the Ugandan Asians in late 1972 that the nexus between official photography and commercial studios advanced still further. Prior to their expulsion, Uganda's Asians had owned practically every studio in the country - most of which were named after their proprietors, as in Fernandez' Studio, Mahmoud's Studio, N.V. Mohamed's Studio, Patel's Studio, Prabbat's Studio - and Asians had also controlled the big commercial agencies for developing film in Kenya (at the time, the largest of these was the Kodak agency, which processed all of its colour film in Nairobi). ${ }^{19}$ However, following the expulsions, and the seizure and redistribution of their businesses, a majority of

16 Interview with former Section photographer, Kampala, 30 May 2019.

17 Interview with Dick Kasolo, Kampala, 15 March 2019.

18 Interview with Elly Rwakoma, Bushenyi, 16 March 2019.

19 At that time, there were no commercial colour processing facilities in Uganda. 
these studios throughout the country were taken over by high-ranking army officers. And as described to me by Ssemuju, ${ }^{20}$ one of the Photographic Section's, and later the presidential media unit's, most senior cameramen, the assumption was that all of the studios in the capital were taken over by military men. ${ }^{21}$ One of these studios, on the corner of Kampala and Entebbe Roads in downtown Kampala, as well as the national Kodak agency, were taken over by Wamala, who did so well with his new businesses, that he was soon able to set up a number of additional studios. However, the nexus between government and studios was to reach its zenith in 1978, when the Section opened its very own commercial studio - accessible to all members of the public - underneath the newly built Uganda House, also on Kampala Road. Already by the time of its official launch, by Idi Amin himself, this studio was amongst the best equipped in Uganda, and its primacy was shortly afterwards confirmed by its purchase of the first commercial colour photo printer in the country. ${ }^{22}$

Yet so too, the Ministry's photographic operation was deeply affected by the growing presence of international photojournalists in Uganda. Reflecting how internationally newsworthy Idi Amin's actions quickly became, from the time of his coup détat on 25 January 1971 onwards, an increasing number of international press corps focused their attention upon the country. And once again reflecting Amin's own 'love of all things media, a majority of these international journalists were initially warmly embraced by the new president, and in some cases went on to develop good personal relations with him. In regard to photojournalists specifically, one of the first people on the scene at the time of the coup was a UK-born freelancer called Marion Kaplan. She arrived as Amin was conducting a victory parade in downtown Kampala, and took a number of photographs that were later collected under the title 'Amin Rides In'. The collection included images of a tank moving through the arched entranceway to Uganda's parliament; a group of soldiers driving through the capital atop an army jeep; a group of cheering women welcoming the incoming military force; and a huge crowd thronging the Kololo showgrounds (Figure 1) (at which Amin gave his inaugural address). ${ }^{23}$

Rather ominously, it also included a photograph of an alleged opposition member being led away at gunpoint by a group of policemen and soldiers. Over the following years, Kaplan went on to become perhaps the most active international photojournalist operating in Amin's Uganda. For example, in 1972, she returned to the country to take pictures for a story on the first anniversary of the coup, which had been commissioned by The Times of London. These pictures included a personal portrait of Amin, but were mostly taken up with images of 'everyday life', and included images of tourism, industry and 'modern' urban life (the collection was subsequently

20 Interviews with Ssemuju (a pseudonym), Uganda, May 2019 and March 2020.

21 The belief being that where a civilian manager was operating the business, this person was just a 'front man' for a military owner.

22 The official opening of the studio by Amin is recorded in the UBC archive, in a packet entitled 'Uganda House Visited by His Excellency' (10/9/1978). The UBC's negatives are stored in glassine envelopes, each of which is carefully numbered and catalogued, and contains a set of negatives. Throughout this article, I will refer to these envelopes as 'packets'.

23 The full sequence 'Amin Rides In' is in the Camera Press archive. See also M. Kaplan, Focus Africa: A Photojournalist's Perspective (London: Elm Tree Books, 1983), 158-64. Two of the photos in the Camera Press archive are also reproduced in that book, on pages $158-9$ and $162-3$, respectively. 


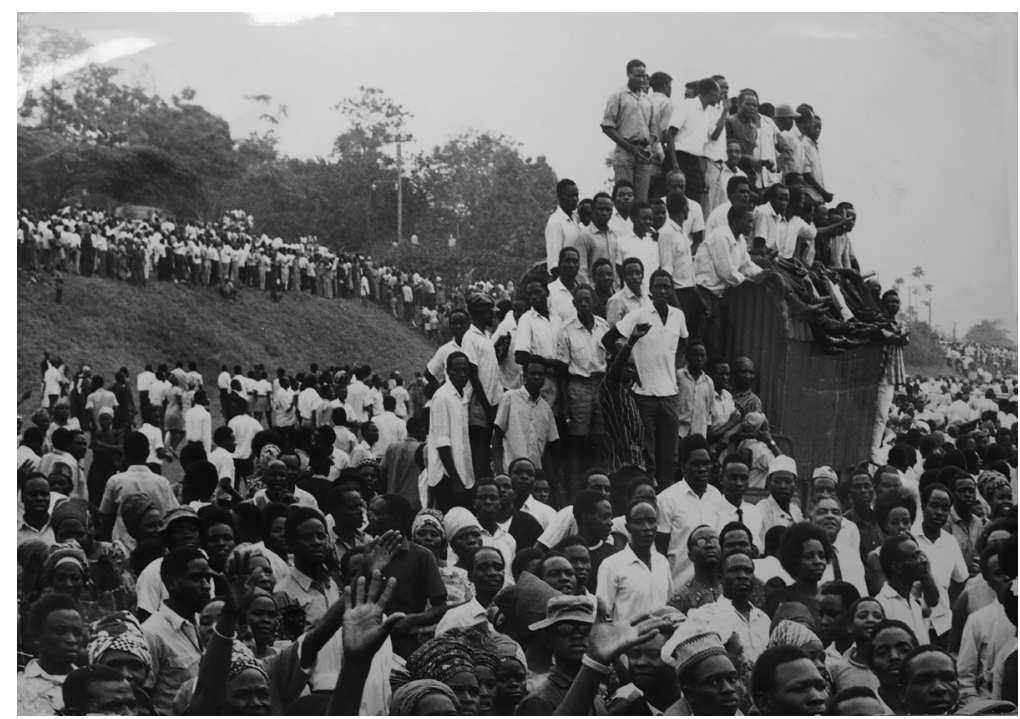

Figure 1: Image from a series captioned 'Uganda's New Leader: Amin Rides In'. Reproduced by kind permission of Camera Press.

entitled 'Jungle and City: The Other Side of Uganda'). In 1974, Kaplan came back to Uganda to shoot pictures of Amin presiding over a graduation ceremony at Makerere University, and a military march-past at Nakivubo Stadium (the collection was called 'Big Day for Big Daddy Amin'). And in January 1976, she returned again to take pictures of Amin's public celebrations for the fifth anniversary of his takeover, at the centre of which was a major military parade through Kampala. This included a flypast of Russian-built MiG fighters flown by Libyan and Palestinian pilots ('Amin's Tank Parade'). ${ }^{24}$ Yet there were many other international photojournalists who visited Uganda during the Amin years to work on various stories about the regime, including Hans Bollinger, John Downing, David Lomax, Sven Simon and Adrian Sutton (Figure 2).

However, the most important of these actors, for my story here, was the Kenyanborn and Nairobi-based cameraman Mohamed Amin, who for clarity I shall refer to throughout the remainder of this article by his common nickname 'Mo'. Although in the period immediately following Idi Amin's rise to power, Mo had been committed elsewhere - he was in Dacca, covering the Bangladesh Liberation War at the time - as with Kaplan, he too went on to make several visits to Uganda during the 1970s, during which he produced a range of stories using both still photography and film. For example, I know that he covered the expulsion of the Ugandan Asians in 1972, ${ }^{25}$ that he was with a delegation of Canadian journalists who interviewed Idi Amin in early

24 Ibid., 165, 177.

25 See B. Smith and S. Amin, The Man Who Moved the World: The Life and Work of Mohamed Amin (Master Publishing, 2012), 62. 


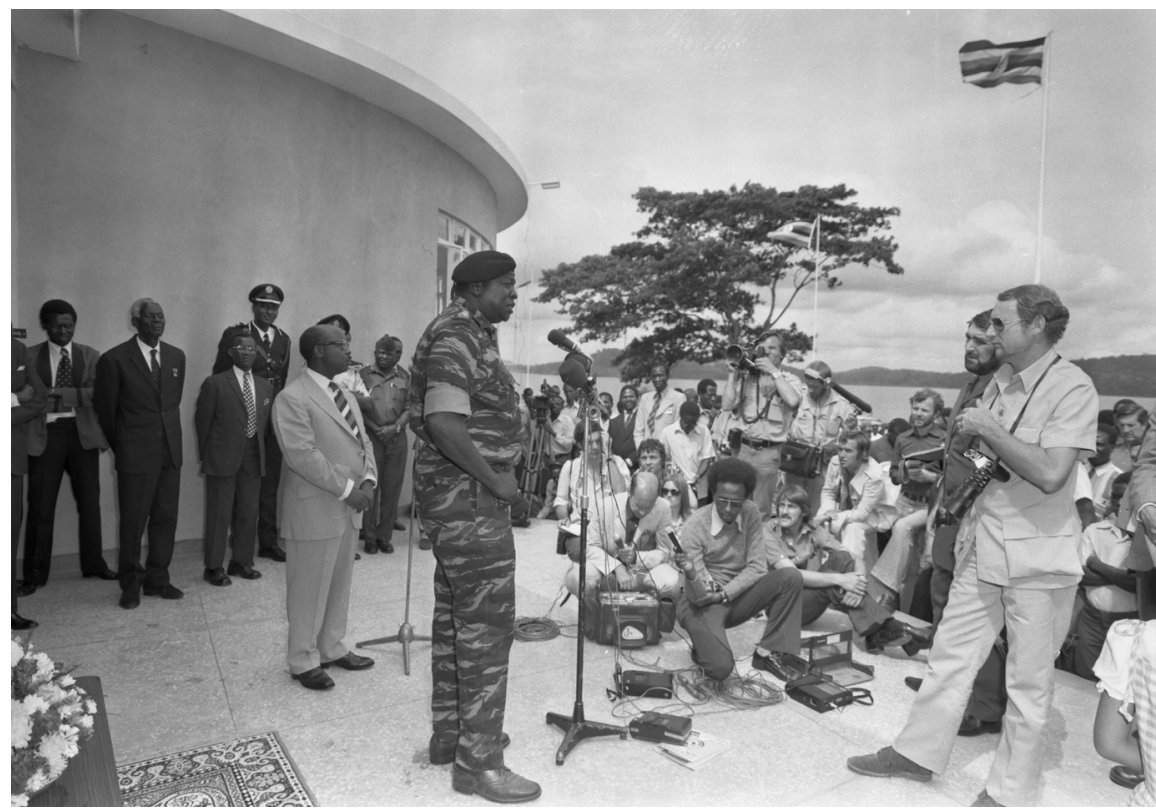

Figure 2: The international press corps attends President Amin's opening of Jjajja Marina, Munyonyo, July 1975. Reproduced by kind permission of the Uganda Broadcasting Corporation.

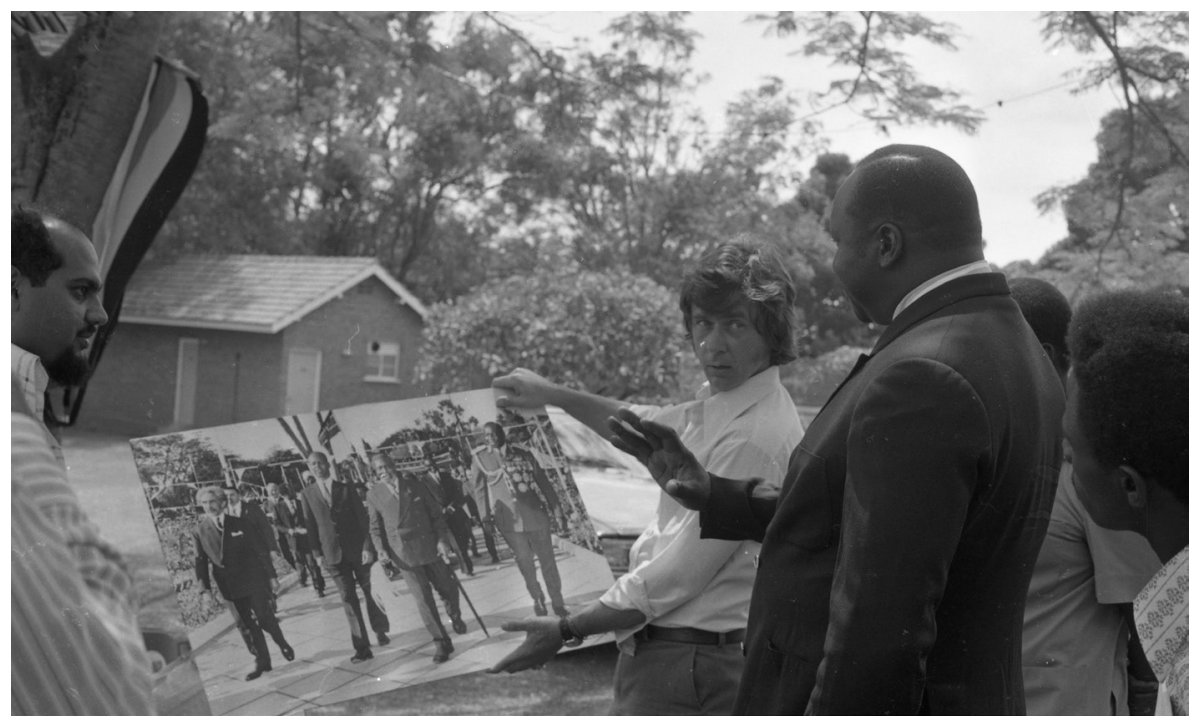

Figure 3: Mo Amin (left) and Canadian journalists meet President Amin at Nakasero Lodge, Kampala, January 1975. Reproduced by kind permission of the Uganda Broadcasting Corporation. 
$1975,{ }^{26}$ and that he returned to Uganda to cover the Organization of African Unity (OAU) meeting that took place in Kampala in July-August of that year (Figure 3).

Moreover, across all of these visits, he appears to have also developed a good relationship with Idi Amin. This is most clearly evidenced by the fact that it was Mo who secured the first television interview with Amin, following his overthrow in April 1979. The still photographs of the interview - which was conducted by the BBC's Africa correspondent Brian Barron at Amin's new home in Jeddah, Saudi Arabia $^{27}$ - include a jovial portrait of Mo and Idi Amin posing together. Yet of greater significance for my story here, in addition to his own work as a cameraman, Mo was also the founder-operator of a Nairobi-based commercial picture agency called Camerapix - which throughout the 1970s also regularly purchased photographs, from all kinds of photographers in Uganda, for onward sale to media organisations throughout the world. And one of the main customers for Mo's pictures, both for the ones he took himself and for those his agency had purchased from third parties, was the very same, London-based, Camera Press.

\section{Photographic Circulations and Their Concealment}

So how did all of these things - the continuities with earlier practice, the emergence of alternative circuits of state photography, and the growing nexus between all kinds of official and commercial photographies - combine to shape or restrict circulations of the Photographic Section's images throughout the Amin period, both in Uganda and beyond?

The first point to make here is that during the early years of the Idi Amin regime, at least, the Photographic Section continued to output visual artefacts that were clearly aimed at communicating official messages of progress and development to Ugandan audiences. The clearest examples of this were two Ministry of Information booklets that were published to coincide with the first and second anniversaries, respectively, of Amin's rise to power: The First 366 Days and The Second Year of the Second Republic. ${ }^{28}$ The books were divided into a series of chapters, each of which in turn took as its topic one or other event, or political development, of the preceding 12 months. In all instances, the said event/development was then used as a lens through which to explore some deep-seated social or political issue in Uganda, in a way that emphasised the imagined progress that the new government had made in relation to it. For example, The First 366 Days, which was largely written by a UTV journalist called Henry Mitima, is 91 pages long and includes chapters entitled 'Uganda Buries Her First President', 'Uganda to Remain a United Republic' and 'President

26 Mo can be seen in the Section's photographs of the visit, which are in UBC packet 4479. In one UBC image (4479-006), Mo and a Canadian journalist are seen showing Idi Amin an oversize print of a heads of state meeting he had attended. The print shows (from left to right) Haile Selassie, Siad Barre, Jomo Kenyatta, and Idi Amin himself. In the UBC photo, Amin appears to be enthusiastically narrating the scene to the two newsmen.

27 The story is recounted in Smith and Amin, The Man Who Moved the World, 69-71. However, the location of the interview with Idi Amin was still secret when it first broadcast, one result of which is that the Camera Press archive captions refer to its stills as being in 'an unnamed Arab country'.

28 Ministry of Information and Broadcasting, The First 366 Days (Entebbe: Government Printer, 1972) and Uganda: The Second Year of the Second Republic (1973). 
Amin Moves to Revive the Shattered Economy'. And although the Ministry committee which oversaw the publication could not agree on a single, unifying image for the book's cover, the body of the text is richly illustrated with Section photographs, and with reproductions of image-rich newspaper front pages. So too, during the early years of the Amin government, Section photographs continued to be taken with a view to national publicity, and especially with a view to tourism promotions. Indeed, the Section continued to employ at least one photographer who was dedicated to tourist publicity. However, it is also the case that within a short period, the circulation of this material dropped off to practically zero, in line with the wider collapse of Uganda's tourist sector. In September 1973, Amin declared a 'Uganda Welcomes Tourists Day' in an attempt to revive the beleaguered industry. However, as Marion Kaplan, who was one of the international photojournalists who visited for the Day, describes, the event did little more than highlight how far the once thriving sector had by then fallen. ${ }^{29}$

In addition, between 1971 and 1975, the Photographic Section continued to provide prints to the Ministry's Film Unit, and to UTV, for use as stills in informational films and in television news reports. And they continued to also contribute at least some pictures to the government-owned international news directorate, as illustrations for stories being sent out 'over the wires'. It is impossible to know precisely how many of the Section's photos were distributed through these three channels. However, some clues are provided by the fact that the Ministry's headquarters, along with the Film Unit, UTV and the news directorate, were all located in the same compound of buildings, sited at the top of Nakasero Hill in Central Kampala. In 2006, the entire compound was sold to a private conglomerate, the Aya Group, for the construction of what eventually became the Pearl of Africa Hotel. ${ }^{30}$ Following the sale, two UBC employees, Dean Kibirige and Faustin Misanvu, launched an initiative to save all of the archival materials at the compound, and to move them down to the UBC's current headquarters, located about one kilometre away, on Nile Avenue. ${ }^{31}$ Kibirige estimates that as part of this move, the pair moved approximately ten boxes of photographic prints, each of which contained roughly fifty prints, a majority of them from the 1960 s and the early 1970 s. $^{32}$ Although it is difficult to draw any firm conclusions from this, it does suggest that the Photographic Section continued to contribute prints to these other branches of the official media apparatus, and at a reasonably steady rate, during the early years of the Amin period, as least (although not after 1976, as described below).

29 Kaplan's account of her visit for the event describes Uganda's hotels as 'empty', and observes that 'shortages were acute and shabbiness, due to lack of parts and proper maintenance, widespread'. Kaplan, Focus Africa, 170.

30 After several financing and construction delays, the Pearl of Africa was finally opened in 2017. The approximately US $\$ 300$ million, 300-room hotel today dominates Kampala’s skyline.

31 The pair hired a truck using their own money, and used this to ferry several loads of archival materials from the Nakasero site down to the UBC's headquarters on Nile Avenue. Most of this material arrived on a Friday - as a result of which it sat out on a verandah over the following, and very rainy, weekend.

32 Interview with Kibirige, Kampala, 3 March 2020. In 2015, I examined a box of prints at the current UBC headquarters which contained 62 photographs, mostly from the 1960s. Scholar Alicia Decker has also described looking through boxes of prints at the Nakasero site in the early 2000s - and she subsequently reproduced a number of these in her book, In Idi Amin's Shadow: Women, Gender, and Militarism in Uganda (Athens, OH: Ohio University Press, 2014). 
The Photographic Section also continued to contribute at least some of their pictures to Ugandan newspapers, and especially to the Voice of Uganda. However, it is also true that the Section's circulations to the national press became quickly curtailed - both as newspapers built up their own photographic capacity (for example, the Voice employed a number of photographers of its own, the most senior of whom was one Jimmy Parma) and, even more so, as commercial photographers increasingly encroached into this same area. Simply put, whereas previously the Section would have automatically supplied Uganda's newspapers with more or less all of their pictures free of charge, with the growing influence of commercial photographers such as Manu Kanani and Elly Rwakoma, newspaper editors now had a much wider range of options to choose from when illustrating their articles. In addition to the Section's images, and those produced by their own cameramen, editors could now also select from pictures that had been taken by these commercial photographers - even if the latter did 'cost a little more' (and as all of my respondents have consistently agreed, in Amin's Uganda, the imagined 'impact' of any newspaper article, or indeed of any media story, always took precedence over the costs of its production). One result was that some photo studios were soon making more money from their media work than from their 'normal' studio portraiture. For instance, Elly Rwakoma estimates that he was making the lion's share of his income this way, as he regularly took pictures at public events and sold them to newspapers (he was paid according to the size at which they were subsequently reprinted, and according to how 'sensational' they were). ${ }^{33}$ Another was that the Section itself even began to 'buy in' the odd studio photo for inclusion in its own collection, presumably when its own photographers had 'missed' a picture, or when their shots were deemed inferior to those taken in the studio. For example, I know of at least one studio portrait, of Brigadier Isaac Maliyamungu's wedding party, which was taken at Manu Kanani's old studio on Wilson Road although after Kanani had left the country - and later incorporated into the Section's catalogue in this way (Figure 4).

However, by far the most significant effect, for my story here, was that as the Photographic Section became increasingly drawn into a wider market for photographs, so too it started to sell ever more of its own images. According to Ssemuju, from the outset, these sales were always highly regulated, such that although they could be initiated by any of the Section's individual photographers, each had to be signed off by the minister himself, using a dedicated form. As a result, in theory at least, the photographers themselves were not allowed to make any money from the sales of their own photographs, with the profits instead accruing to the Ministry (and it is noteworthy that these transactions were apparently not only quite lucrative, but were generally paid in hard currencies such as US dollars). ${ }^{34}$ However, Ssemuju concedes that at least some of the Section's men probably did sell images 'on the side' as well. On the question of to whom these sales were being made, it appears that following the establishment of the international news directorate in 1970, the Section's photographs 


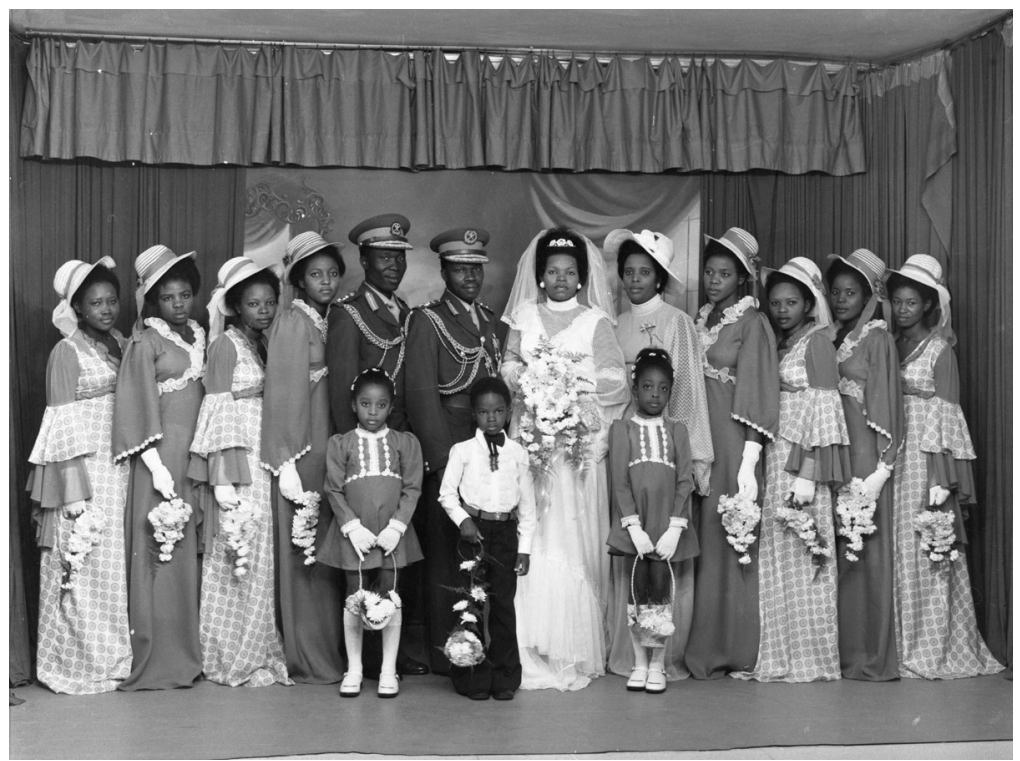

Figure 4: Brigadier Isaac Maliyamungu's wedding portrait, taken at Manu Kanani's former studio on Wilson Road, Kampala, 1978. Reproduced by kind permission of the Uganda Broadcasting Corporation.

were no longer sold directly to Camera Press. However, I do know that between 1971-6, they certainly were being sold to a number of other international media organisations, including the BBC, Reuters and Drum magazine (in South Africa). Yet throughout this period, the Section's biggest customer appears to have been Mo's Camerapix, which then sold some of them on to Camera Press. (One peculiar effect of this was that although the Photographic Section stopped sending images directly to Camera Press, the volume of their images reaching the London agency - seemingly through Mo's brokerage - in fact increased after 1971.)

In early 2016, I was granted research access to Camera Press's entire physical picture archive from Uganda, which is today stored in the company's main warehouse, in the London Borough of Barking and Dagenham. The archive, which is made up of approximately 2800 images,${ }^{35}$ consisting of around $2400 \mathrm{~B} \& \mathrm{~W}$ prints and roughly $40035 \mathrm{~mm}$ colour negatives, contains images from 1952 up until the early 1990s. ${ }^{36}$ However, the vast majority of them are images of the Amin regime and its aftermath, which reflects just how 'newsworthy' both the man himself and his government were at the time. As one would expect, the Camera Press archive contains images that are credited to Marion Kaplan, and to various of the other international photojournalists named above (and in most cases, these are grouped into named collections - referring to some or other event, or photo story - as described in relation to Kaplan's work, 


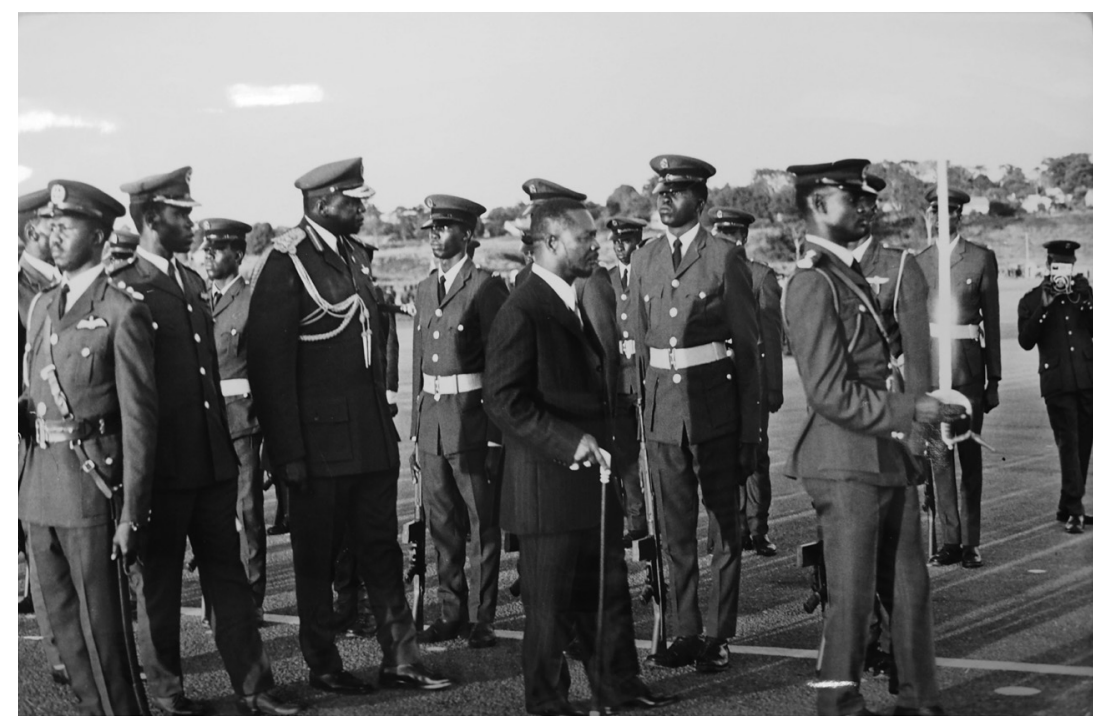

Figure 5: Image from a series captioned 'President Bokassa in Uganda: General Amin Plays Host'. Reproduced by kind permission of Camera Press.

above). However, the archive's largest number of images from the 1970s are credited either to Mo, or - much more frequently - to Camerapix. Specifically, the archive contains around 90 prints and slides that are credited to Mo personally, and around 250 that are credited to Camerapix. Of the latter, in many instances it is impossible to say with certainty who took the individual pictures, and/or how they came into Camerapix's possession. In other words, for many of the pictures that are credited to only Camerapix, it is impossible to say whether these were also taken by Mo himself, or else by another commercial photographer, or an international photojournalist, or a Photographic Section cameraman, and then later sold on to the Camerapix agency. In all likelihood, the 250-odd images that are credited to Camerapix include a combination of all of these. Camerapix itself, which is today run by Mo's son, Salim Amin, does not appear to have retained any records that might provide further clarification here. In a recent discussion over the provenance of another set of photographs of Idi Amin, which may have been taken either by Elly Rwakoma or Mo, Salim was unable to provide any guidance. ${ }^{37}$

Nevertheless, I can still say with a good degree of probability that at least some of the images in Camera Press's archive that are credited to Camerapix were taken by Section photographers. For example, one Camera Press (Camerapix) print, which is captioned 'General Amin Plays Host' and depicts a state visit to Uganda by President Bokassa of the Central African Republic in August-September 1972, was almost certainly taken by a Section cameraman (Figure 5).

37 In relation to those other pictures, Salim is quoted as saying: 'I am under the impression that my father took those images but he may have purchased the negatives from Elly Rwakoma...I cannot confirm any more than that as I was not even born then.' See 'Elly Rwakoma: Photographer of Presidents', The East African, 19 March 2016, https://www.theeastafrican.co.ke/magazine/ Elly-Rwakoma--Photographer-of-presidents--/434746-3123332-k8holn/index.html [Accessed: 23 April 2020]. 


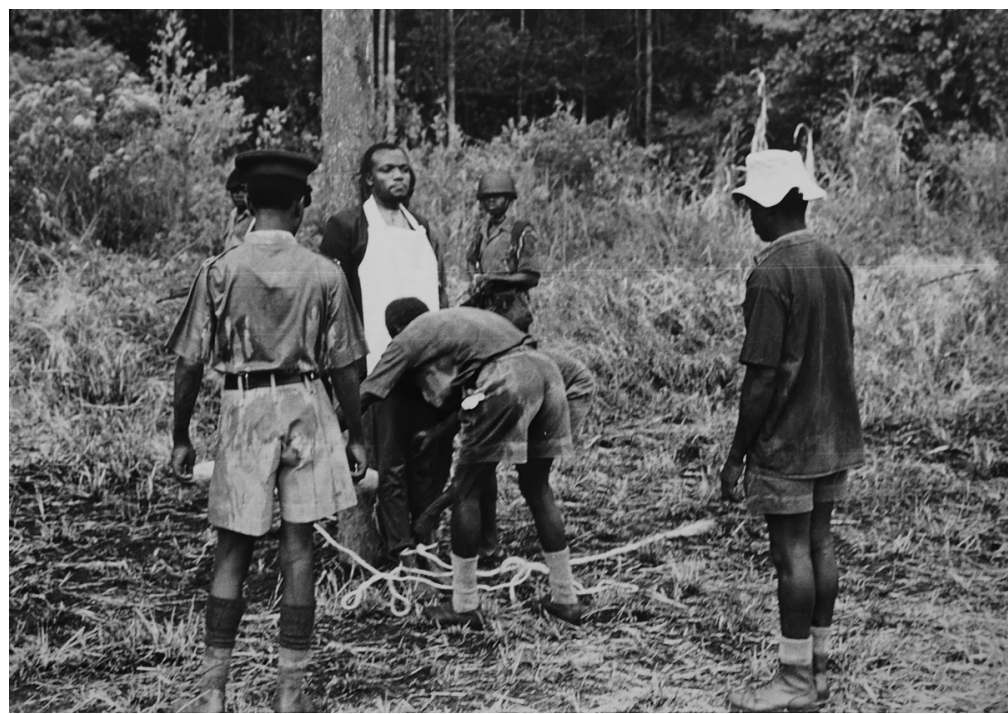

Figure 6: Image from a series captioned 'Amin's Example to Others: Public Execution in Uganda'. Reproduced by kind permission of Camera Press.

Although the negative for this print is no longer in the UBC's archive, various elements of the picture - including the position of the photographer, the framing of the image and the position of its subjects - suggest that it was very likely taken on the same roll of film that forms a sequence across UBC packets 3351-1 to 3351-3. Similarly, a set of Camera Press (Camerapix) prints that are captioned as 'Exit the Asians - Enter the Arabs', which picture the arrival at Entebbe Airport of a group of Egyptian technical experts who had been invited into Uganda to replace departed Ugandan Asian technocrats in 1973, likely correspond to the images contained in UBC packet 3462. And in the most striking examples, a series of 12 Camera Press (Camerapix) prints, collectively captioned 'Public Execution in Uganda' and depicting the executions at Mbale of two men, Sebastiano Namirundu and Tom Masaba, on 10 February 1973, for their alleged role in the botched invasion of Uganda by Tanzanian-based exiles five months previously, were again almost certainly taken by the Section's photographers. Although the negatives for these prints are also no longer in the UBC archive, I know the Section's cameramen were tasked with documenting all public executions during this period - and that other photographers were barred, by presidential decree, from attending those same events. Moreover, both the framing and the sequencing of the 12 images of the Namirundu-Masaba execution bear striking similarities to the one set of images of a public execution that have survived in the UBC archive (packet 3482) - which are of the execution at Tororo of one Sergeant Baru, on 27 June 1973 (Figure 6).

Moving beyond the Camera Press archive, I know of at least two other cases of photographs that definitely were taken by Section photographers, having been sold on to Camerapix. The first case relates to three images of the Baru execution: the first pictures the condemned being blindfolded before he is killed; the other two show his 


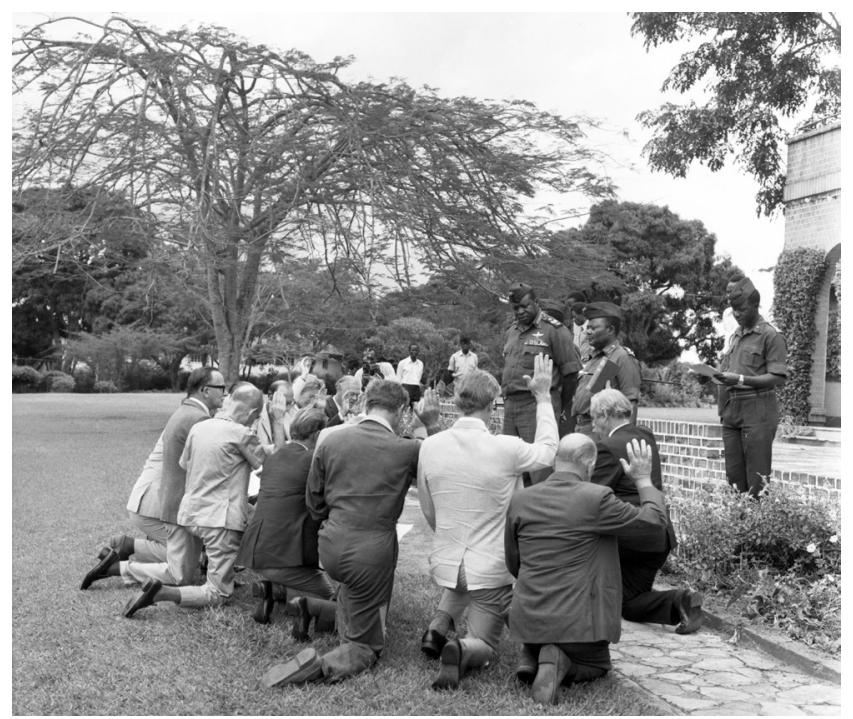

Figure 7: President Amin presides over a ceremony at which British expatriates take Ugandan citizenship, September 1975. Reproduced by kind permission of the Uganda Broadcasting Corporation.

dead body being taken down after his execution. The three images are today in the archives of a Camerapix spinoff called Africa 24 Media, which was set up by Salim Amin in 2008. ${ }^{38}$ Although the negatives from these three pictures are also no longer in the UBC archive, these images are unquestionably part of the same sequence of images - shot on the same roll - that was produced by a Section cameraman to document all stages of the execution process, and which is still in the UBC archive (in the aforementioned packet 3482; this packet contains 11 other images from the same sequence, eight of which are reproduced, in chronological order). ${ }^{39} \mathrm{~A}$ fourth image from the Baru execution, which is again part of the same series contained in UBC packet 3482, is today held in the archive of another London-based picture agency, AKG Images, having been apparently also purchased by them from Camerapix (although the image is mislabelled in AKG's catalogue as relating to the earlier executions at Mbale). ${ }^{40}$ Interestingly, this latter image is perhaps the most haunting from the entire Baru series, not least because it is the only one in the whole set that shows the condemned man's face. ${ }^{41}$ The second case that I know of relates to an image of an oath-taking ceremony, in which a group of British expatriates working for the Ugandan government, led by Bob Astles, are pictured kneeling down in front of Idi

38 The three images have been latterly published online, watermarked with the Africa 24 Media logo. See http://atrocities-ofamin.blogspot.com/2008/02/captain-olal.html [Accessed: 23 April 2020].

39 Some of this sequence is reproduced in Peterson and Vokes, The Unseen Archive, 130-5. Ssemuju has confirmed that the whole series of the Baru execution was taken by one of his colleagues in the Photographic Section. Interview with Ssemuju, Uganda, March 2020.

40 In this particular case, the fact that the four negatives for these images are missing from UBC packet 3482 may itself be significant. Specifically, it may suggest that at the time of their sale, the Section photographer involved felt that it was safer to sell the negatives, rather than any prints made from them. In a context in which Idi Amin had banned commercial photographers from attending public executions, this may have been a sensible way for the photographer to try to 'cover his tracks'.

41 See https://www.akg-images.co.uk/archive/-2UMDHUWBEFI80.html\#/SearchResult\&ITEMID=2UMDHUWBEFI80\&POPU PPN=1\&POPUPIID=2UMDHUWBEFI80 [Accessed: 23 April 2020]. 
Amin and raising their right hands in solemn vow, as part of a citizenship ceremony held on 29 September 1975 (Figure 7).

In this case, the negative of the picture is in the UBC archive (catalogue number 4938-012). Further, this particular photograph is one of a sequence of 11 images in the UBC holdings that once again, in combination, document the citizenship event as an entire process (these images are all in packet 4938). ${ }^{42}$ And according to Ssemuju, he was the photographer that took this whole series. ${ }^{43}$

\section{The Entebbe Raid, 1976}

Yet even if the Photographic Section's biggest customer was Camerapix, its images were also sold to other picture agencies besides. And it was its sales to another media organisation, Drum magazine, following the infamous Entebbe Raid on 4 June 1976, that was eventually to be its downfall. Briefly stated, this was the incident during which Israeli commandos stormed Entebbe Airport, to free hostages who were being held there following the hijacking of an Air France plane by the Popular Front for the Liberation of Palestine. ${ }^{44}$ Following the raid, one photographer with the presidential unit, who had been with Amin in Mauritius at the time the action took place, and who had flown back with the president to Uganda, was immediately tasked with photographing the entire scene. As this photographer (whose identity I have decided to keep anonymous) described it to me: 'As soon as I got off the plane, I started taking pictures. I took so many pictures, about 200. I wish I could show you those pictures... you would cry! We really lost people.' Over the following days, he also documented the funerals of the Uganda servicemen; a visit by Amin to the injured servicemen in hospital; and the charred remains of Dora Bloch's body (after she had been killed by the SRB). Shortly afterwards, the Section received a request to share some of these pictures with the Voice newspaper (whose own journalists had not been allowed access to the scene), which were delivered to Jimmy Parma. Upon receiving the images, Parma promptly sold on a selection of the shots to Drum magazine in South Africa, which in turn used them to illustrate articles about the Entebbe Raid. For example, a 1994 anthology of Drum articles on Uganda reproduces six of the photos, in a reprint of one of the articles in question (Figure 8). ${ }^{45}$

42 Camerapix's image, which is in fact a tight crop from the above negative, can be viewed at https://trueafrica.co/article/moamins-son-on-using-his-legacy-to-tell-todays-african-stories/ [Accessed: 23 April 2020]. Interestingly, a print of the same image is also found in the Camera Press archive, but that copy is credited neither to Mo personally nor to Camerapix, but to another source entirely. This suggests that it was circulated not only via Camerapix, but through multiple channels. At least one other image from the sequence of 11 in the UBC's archive (catalogue number 4938-002) was also circulated outside of Uganda, although we do not know through which channels this other one passed. It can be viewed at https://www.cbsnews.com/ pictures/idi-amin/16/ [Accessed: 23 April 2020]. Interview with Ssemuju, March 2020.

44 The raid resulted in the death of the Israeli force commander, Lt-Col Yonatan Netanyahu, and 45 Ugandan soldiers, and in the destruction of a number of Soviet-built warplanes belonging to the Ugandan air force. Of the 105 hostages being held in the airport building - the majority of whom were Israeli passengers, with a smaller number of Air France crew - 3 were killed in the firefight, with the remaining 102 flown to safety. However, one other hostage, a 74-year-old Israeli passenger called Dora Bloch, who had been receiving hospital treatment at the time of the raid, remained behind in Uganda. Following the raid, Bloch was taken away from the hospital by the director of the SRB, Farouk Minawa, and killed.

45 The anthology was originally published in South Africa, in 1994. My references here are to the Ugandan reprint of the book, which was published as Uganda: The Bloodstained Pearl of Africa (Kampala: Fountain, 2010). The images to which I am referring here are reproduced on pp. 166-9. 


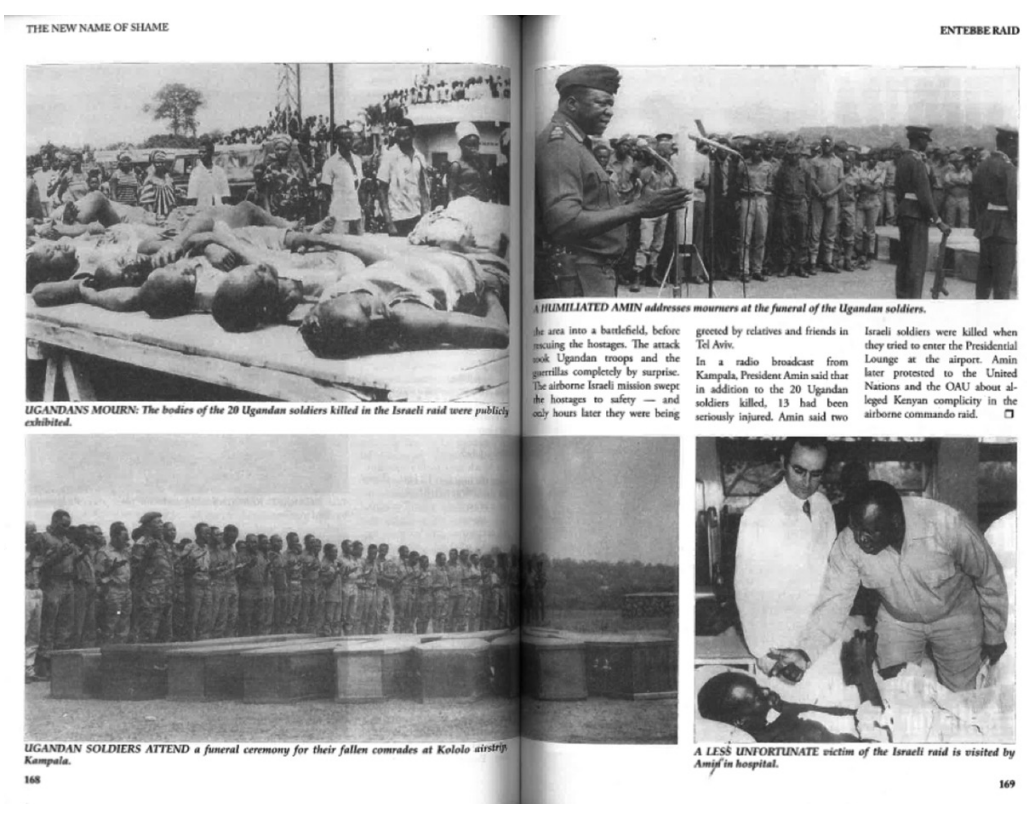

Figure 8: Photographs taken of the aftermath of the Entebbe Raid. From Uganda: The Bloodstained Pearl of Africa (Kampala: Fountain, 2010).

When Amin learned of the photos' inclusion in the Drum articles, he flew into a rage and ordered an immediate investigation into their provenance. The photographer who had taken the images, who because of his role had good contacts at State House, got wind of the situation and managed to go to ground. However, neither the Room 10 office messenger - who had delivered the photographs - nor Jimmy Parma was as lucky. Both men were soon picked up by SRB agents and killed, with Parma's body being later dumped on a bridge just outside Kampala. Interestingly, Mo had also been with Idi Amin at the OAU summit in Mauritius, and had been invited by him to travel back to Uganda on that same presidential flight. However, at the last minute, Mo had decided not to take up Amin's offer, in a decision that, he later reflected, probably saved his life. ${ }^{46}$

For the Photographic Section, the killings of their office messenger and of Parma were not the end of the official sanction. According to the photographer who was involved here, once he eventually came out of hiding and returned to work, he learned that shortly after the killings, a group of SRB men had descended on Room 10, and had proceeded over the course of a month to purge the Section's catalogue not only of all images of the Entebbe Raid, but of any others that they deemed questionable as well. Among the pictures taken out were numerous sets of images relating to all public

46 As Mo later told his biographer, Brian Tetley: 'If I'd stayed on that flight, I would have certainly gone to Entebbe after the raid, and just as certainly, I would have been killed. Neither Idi Amin, nor anyone around him, would have hesitated. That loss of face was his biggest humiliation. Anybody trying to film it for the world to witness would have been dead. B. Tetley, The Story of Mohamed Amin: Frontline Cameraman (Master Publishing, 2013), 96. 


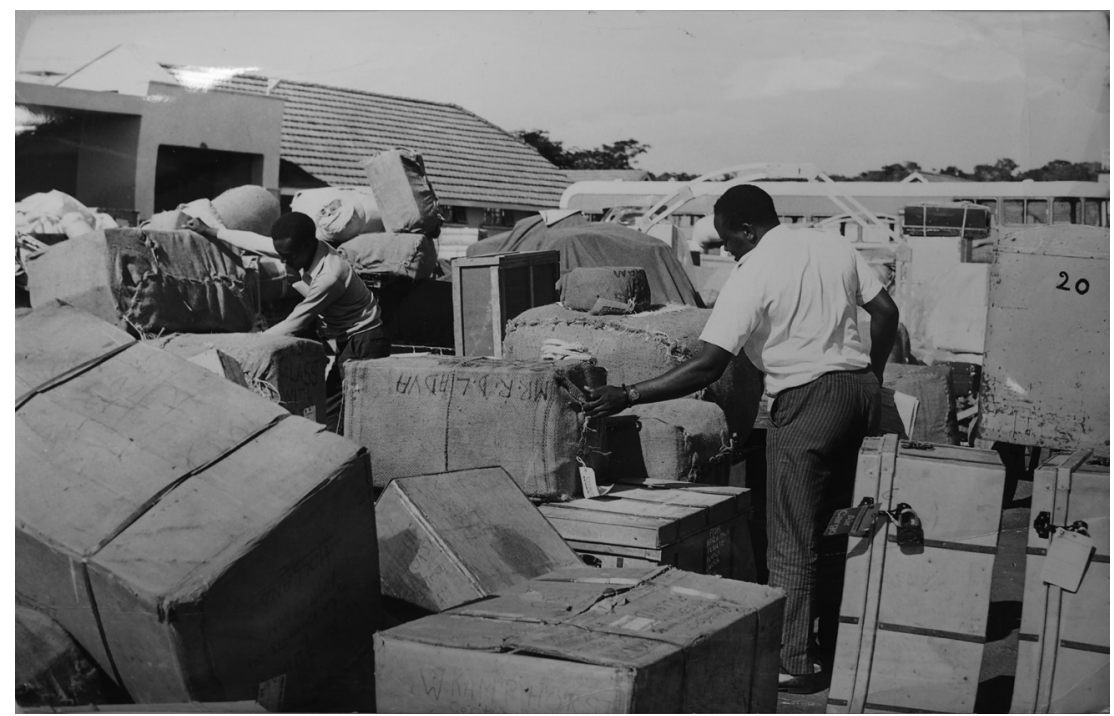

Figure 9: Image from a series captioned 'Asians in Uganda: The Exodus Begins'. Reproduced by kind permission of Camera Press.

executions, including those of the Mbale executions; ${ }^{47}$ the Asian expulsions; various military parades in Kampala; Amin's various 'anti-imperialism' drives; a punishment beating of alleged prostitutes that had been conducted in the grounds of the SRB building; and various other subjects besides. Interestingly, several of the subjects described here, in addition to the Mbale execution images, also correspond to images in the Camera Press archive that are credited to Camerapix. For example, the Camera Press (Camerapix) holdings include dozens of images of the Asian expulsions, taken in Uganda. ${ }^{48}$ Although Mo did take a lot of his own pictures in the lead-up to that event, ${ }^{49}$ these holdings include at least some scenes to which no photojournalist would likely have been given access. For instance, the Camera Press (Camerapix) prints include a series of close-ups of SRB men going through piles of Ugandan Asians' belongings at Entebbe Airport (Figure 9).

So too, the Camera Press (Camerapix) prints include more than 30 images of two military parades in the Ugandan capital that were held to mark the fourth and fifth anniversaries of Amin's accession to power, in 1975 and 1976, respectively. The images from the second of these are especially striking, showing as they do a column

47 And the assumption here is that the set of negatives relating to the Baru execution only survived because they were missed in this purge. Certainly, at the time we began working on the archive, the packet in which these images are located, 3482 , was located well out of sequence.

48 Indeed, the London agency has far more pictures on this event than on any other subject in the country's history - and it also includes several collections of pictures of Ugandan Asians taken after their arrival in Kenya and the UK.

49 He attended an infamous lunch that Idi Amin held for leaders of the Ugandan Asian community, as well as for the High Commissioners of the UK, India and Pakistan, at which Amin had restated his commitment for all Ugandan Asians to leave within a 90-day deadline. Mo filmed the lunch itself, and then took the opportunity while in Uganda to also picture 'long queues of Asians at the British High Commission getting their passports sorted out, and a number of stories around Kampala of traders packing up and selling, even giving away, their belongings'. Mo, cited in Tetley, Story of Mohamed Amin, 80. 
of tanks and mobile artillery passing through the middle of Kampala. ${ }^{50}$ And in another example, the Camera Press (Camerapix) pictures also include a collection called 'Big Daddy's Volunteers', which shows Amin's recruitment drive for Ugandan volunteers to fight on the Arab side in the Middle Eastern conflict.

As described by my respondent, the purge resulted in a huge amount of material being removed from the archive. As he put it, 'all of the negatives were destroyed... No history. Everything was destroyed. ${ }^{51}$ Yet even more profound was the effect that the episode had upon the Section's circulations of its imagery. Because after this episode, the head of Room 10 decided that the organisation's entire archive of negatives should be put under permanent lock and key - in a strongroom at the back of the Nile Avenue office. He also decided that although Section photographers should continue to take pictures as before - 'for the record', as my respondent put it - none of the negatives should be ever again developed into prints. And certainly, after this time, their circulations do indeed appear to have fallen to almost nothing. In the period after the Entebbe Raid, a small number of Section images were subsequently reproduced in the Voice (which reflects the fact that after the death of Parma, the newspaper appears to have stopped taking its own pictures altogether, or buying them from commercial photographers). However, for the period 1976-9, the Camera Press archive contains almost no pictures from Uganda, with the few exceptions being formal portraits of Idi Amin. Indeed, reflecting on this absence, I asked my respondent whether he thought that any Section cameramen might have sold any pictures to agencies like Camerapix after Entebbe, to which he replied, with great incredulity, 'How?! That would have been suicide!'

However, the Camera Press (Camerapix) holdings do include one other set of images from Uganda in the 1970s, namely a large collection of over 100 prints that are variously entitled 'The Liberation of Uganda' and 'The Uganda-Tanzania War'. Both of these collections are constituted primarily of close-ups with frontline Tanzanian troops in action, as they fought their way into Uganda from October 1978 onwards. The pictures depict the Tanzanian soldiers not only on manoeuvres, but in several cases engaged in active firefights. They include images of the troops being greeted by cheering crowds as they enter some or other Ugandan town. However, most strikingly of all, both of these collections are saturated with images of body horror, including, for example, numerous images of individual dead bodies rotting by the side of the road, one picture of a group of Tanzanian soldiers carrying the dead body of an unspecified Ugandan who has been shot in the head, and an image of another soldier handling a dead colleague's body. Yet the most impactful of these prints is one particular image in which the entire frame is filled with over 60 corpses, laid out in three

50 Interestingly, there is a glassine envelope in the UBC archive that corresponds to the first of these parades (it is named 'Army Take Over Anniversary', catalogue number 4475a-01). However, the envelope is empty. Meanwhile, we can tell from the catalogue numbers that the archive is missing at least one envelope whose date would likely have corresponded with the fifth anniversary parade (envelope number 5109). However, the Camera Press (Camerapix) images of this parade may also include images taken by Marion Kaplan, who we know also attended the event. See Kaplan, Focus Africa, 177.

51 Interview with Ssemuju, Uganda, May 2019. Certainly, a reading of the catalogue numbers around the time of the Entebbe Raid suggests that a significant number are missing. 
rows, many of them naked or partially clothed. ${ }^{52}$ The Camera Press caption on the back of this print reads: 'The heaped bodies of men killed on the Uganda-Tanzania border, and claimed by the Ugandans to be Tanzanians and pro-Obote dissidents.' Once again here, it is possible that these images were taken by Mo himself, from a position of his being 'embedded' with the invading forces, or that they include a combination of images taken by Mo and others.

However, there are again reasons to suspect that at least some of these images may also have come through Room 10. In particular, several sources suggest that it was almost impossible for any photojournalists to get close to the action throughout the first six months of the conflict, at least. For example, as Kaplan writes, 'for journalists and photographers based in Nairobi or coming from other continents, the Tanzania-Uganda war was total frustration. Neither side would allow us near to the action. ${ }^{53}$ Moreover, the Tanzanian Army appeared to have become particularly closed to foreign correspondents, following the killing of four European journalists who had tried to sneak into Uganda on a boat across Lake Victoria. (Although the Ugandan Minister of Information also warned photojournalists that it would be 'suicide' for them to try to enter the country at that time.) As a result, it was not until two days after the fall of Kampala, on Friday 13 April 1979, that the majority of the international press corps gained any access to the country, when a large number of them were flown in on a Tanzanian-chartered flight (following this, the corps took an enormous amount of footage of scenes mostly in and around Kampala, including many images of the now iconic scene of disfigured bodies lying around the compound of the SRB building). The press pack later moved on with the Tanzanian Army to Jinja - and later still to Arua - where they covered some of the fighting. However, the question remains as to where Camera Press's earlier pictures of the conflict, many of them taken close in on the action, may have come from. In this regard, I do know that the Tanzanian Army had at least some photographers of its own throughout the duration of the conflict. Moreover, following the Tanzanians' arrival in Kampala, those same photographers took up residence in Room 10 - and press-ganged several of the Section's existing employees into service, to help run the developing machines, and even to keep up its cataloguing system. Thus, it is quite plausible that Camera Press images of the conflict were in fact taken by the Tanzanian Army photographers, and later sold on to Camerapix via Room 10 - which is to say through the Section's by then long-established circuits of exchange. Finally, the content of the images themselves may also support this thesis. Thus, in addition to the pictures of firefights (above), the Camera Press prints also include a number of other scenes to which no photojournalist would likely have been given access. In particular, they include one blurred, and badly lit, image of a Tanzanian soldier standing in a room full of crates of weapons, and apparently holding a piece of ordnance (Figure 10).

52 For ethical reasons, I have decided not to include a reproduction of this image in this article.

53 Kaplan, Focus Africa, 179. 


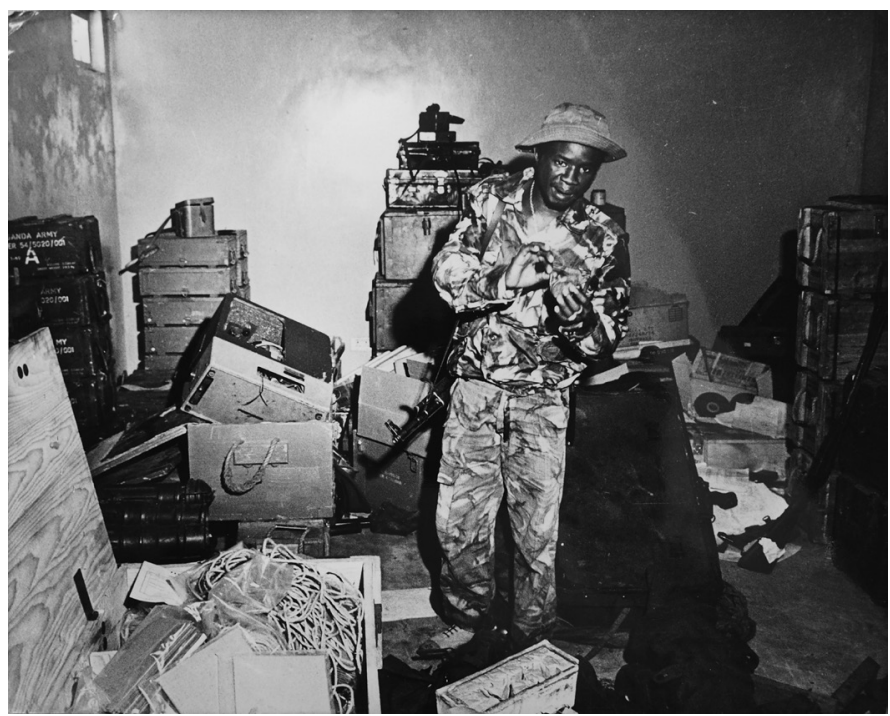

Figure 10: Image from a series captioned 'Kampala: After the Fall of Amin'. Reproduced by kind permission of Camera Press.

Finally, it is worth making explicit what all of these various trends and events did to the overall scale of the Section's circulations over time. Thus, if in the period between 1947 and 1960 the Section had taken 14,000 negatives, during the 1960s, an estimated 38,000 negatives, and during the Idi Amin years, at least 60,640, then its production roughly doubled per decade. Yet whereas between 1947 and 1960, the Section had output 134,400 prints (a ratio of negatives to prints of 1:9), during the period of Idi Amin's rule (from 1971-9) - and even when taking into account all of the possible kinds of circulations described in this article - it distributed a total of perhaps around 500 prints, which produces an equivalent ratio of 1:0.008.

\section{Archival Afterlives}

Since the early 2000s, I have been engaged in reconstructing the total archive of Uganda's Photographic Section, by way of purchasing and/or making copies of all kinds of visual artefacts to which its images contributed. Initially, I did this mostly through postcard and ephemera fairs in the UK and Europe. Latterly, it has been more through all manner of both physical and online auction houses, which have connected me to sellers based all over the world. So too, I have made copies of Section images that are held in all kinds of personal, public, library, museum and university archives in Uganda, the UK, the US and elsewhere. And since 2018, I have also had research access to the extensive archive of Section materials that are still held in their original location, which is now part of the headquarters of the UBC.

The truly global range of locations in which these images are now found, combined with the sheer diversity of the collections within which they now sit, is testament to the extraordinary scale and complexity of the further circulations to which 
they have continued to be subject - in some cases continuously so - since the time of their production. In some instances, contextual traces provide at least a few clues as to the nature of these ongoing circulations, as in the note on a postcard, the letter accompanying a print, and the surrounding archival documents in the UBC's stores. Yet in others, all traces of the circulations are now lost: unknown, forgotten, in some cases deliberately erased. In others still, these circulations have become obscured in other ways besides, in particular when subsequent exchanges have served to obscure the earlier pathways through which they had previously passed. And this is particularly marked for those individual images that have been distributed again, and again, and again. For instance, to cite just one example here - although there are many others as well - the very same image of the citizenship ceremony that was taken by a Section photographer and later sold to Camerapix (above), is today also found in the archives of (at least) Camera Press, Associated Press and Getty Images - all of which appear to have sourced it from different places. Yet so too, the same image is today also widely reproduced on the internet, embedded within all manner of blogs, and websites, and twitter feeds, and it was recently even doing the rounds on WhatsApp. Such is the labyrinthine character of the contemporary global image world. ${ }^{54}$

In this context, then, the process of reconstructing the Photographic Section archive's social biography, from the moments of its production until the present, therefore necessitates a kind of archaeology, a process in which multiple layers must be peeled back, to reveal their situated motivations - political, institutional and personal - and to glimpse the emotions that these engendered. The process has revealed much that was previously concealed. In particular, when in early 2019 my research collaborators and I launched an exhibition of the UBC's images from the 1970s at the Uganda Museum in Kampala, we called it 'The Unseen Archive of Idi Amin.5. At the time, we were using the term 'unseen' in the knowledge that the vast majority of the Section's images from this era were never printed or circulated, and that the archive as a whole had therefore never been properly seen by Ugandan audiences. However, my argument in this article has revealed a further layer of concealment that is at play here as well, in respect of those (few) Section images that were circulated, yet which were never credited as being Section pictures. Yet what other layers of concealment remain still to be discovered here? What other secrets does this archive still hold?

And yet for all of this, for all of this archive's now utterly fragmented, hugely dispersed, and in large parts unknowable, character, it still projects a particular kind of historical luminance out into the world. Or rather, it projects three kinds of light, one for each of the (roughly) three decades under consideration here. Thus, the decade of the 1950s projects the light of a 'golden age', one in which all Ugandans stepped bravely forward towards a bright, new and entirely modern future. Against this, the

And in another example, a number of the very same prints that I consulted in the Camera Press archive in 2016 are at the time of writing being offered for sale on eBay. Among them is one of the images of the Mbale executions (above), which is being offered for a 'buy it now' price of US $\$ 79.95$. See https://www.ebay.com/itm/large-vintage-photo-Amin-Dada-opponentMasaba-execution-Uganda-Africa-1973-/293023040787 [Accessed: 23 April 2020]. For more on the contemporary global image world, see especially P. Spyer and M.M. Steedly (eds), Images that Move (Santa Fe: School for Advanced Research Press, 2013).

The exhibition was co-curated by the author, Derek R. Peterson, Nelson Abiti and Edgar Taylor. 
decade of the 1960s feels, frankly, quite dim, a period for which Uganda's trajectory cannot be easily seen, its future difficult to discern. And then we reach the decade of the 1970s, which burns with a strange penumbra - one in which we can see so many Ugandans embracing an energetic new government, engaging in new forms of cultural expression, singing and dancing in Kampala's swinging scene. And yet... and yet... here is the darkness of public executions, of the Asian expulsions, of war at its most dreadful. Yet even these images bring further murk: although they dominate (both numerically and symbolically) the global press archive of the Amin regime, none of them is in fact typical of the mass violence that occurred in the country during these years. In other words, of the up to 300,000 Ugandans that were killed by the state during these years, most did not die publicly, only one person died in the Asian expulsions (terrible though that event was in so many ways, it did not involve multiple killings), and only a very few people were killed in open fighting. Instead, the tens of thousands who died in Amin's Uganda were mostly killed out of sight, behind the gates of military barracks, or in the dungeons of the SRB, and in ways that precluded them from putting up a fight. And all of these murders took place beyond the lens of any Section photographer. Perhaps then this is the true unseen archive of Idi Amin: all of the pictures, of all of the killings, that were never, in fact, taken at all. Certainly, it is the shadow that falls over all that which does remain.

In the late 1940s, Uganda's Photographic Section was set up in part to project an image of the country out into the world. For the period of the Idi Amin regime, its image is at times difficult to look at, always difficult to see. 